\title{
FACTORS AFFECTING BEHAVIOURS THAT ADDRESS HIV RISK AMONG A SAMPLE OF JUNIOR SECONDARY SCHOOL STUDENTS IN THE NORTHERN PROVINCE, SOUTH AFRICA
}

\author{
Karl Peltzer \\ Professor, Department of Psychology, University of the North \\ Correspondence: peltzerk@unin.unorth.ac.za
}

Key words: HIV risk behaviour; secondary school pupils; South Africa

\begin{abstract}
The purpose of this study was to identify factors affecting HIV risk reduction among junior secondary school pupils in South Africa. The sample included 441 Grade 10 Secondary School pupils in the age range of 16 to 25 years ( $M$ age $16.3 \mathrm{yr}, S D=2.3$ ) from three rural schools in one region of the Northern Province of South Africa. Measures of the following were included: sexual behaviour and condom use, knowledge about correct condom use, intention of condom use, behavioural norms, attitudes, normative beliefs, and subjective norms about condoms, HIV/AIDS vulnerability (likelihood to get it) and severity of the illness in the country, and condom use self-efficacy. Bivariate analysis found positive significant relations between age at first vaginal intercourse, HIV/AIDS susceptibility and severity, attitudes towards condoms, normative beliefs to use condoms as well as subjective norms to use condoms and the HIVIAIDS risk index; inversely related were correct condom knowledge and condom use intention. Regression analysis indicated that inversely correct condom knowledge score, age at first vaginal sex and HIVIAIDS severity were found to be predictive for HIVIAIDS risk behaviour explaining $53 \%$ of the variance.
\end{abstract}

\section{OPSOMMING}

Die doel van hierdie studie was om HIV risiko reduksie faktore onder junior sekondêre skool leerlinge in SuidAfrika te identifiseer. Die steekproef het bestaan uit 441 Graad 10 sekondêre skool leerlinge in die ouderdomsgroepe tussen 16 tot 25 jaar (M ouderdom 16.3 jaar, SD=2.3) van drie plattelandse skole in een streek van die Noordelike Provinsie van Suid-Afrika. Meting het die volgende ingesluit: seksuele gedrag en kondoom gebruik, kennis van korrekte kondoom gebruik, doelstelling met kondoom gebruik, gedragsnorme, houdings, normatiewe oortuigings en subjektiewe oortuigings oor kondome, HIVIVIGS vatbaarheid (moontlikheid om dit op te doen) en die ernstigheid van die siekte in die land, asook kondoom gebruik selfvaardigheid. ' $n$ Tweevoudige ontleding het positiewe beduidende verbande tussen ouderdom by eerste vaginale geslagsgemeenskap, HIVIVIGS vatbaarheid en ernstigheid, houdings teenoor kondome en die HIVIVIGS risiko indeks gevind; omgekeerd verwant was korrekte kondoom kennis en kondoom gebruik doelstelling. Regressie ontleding het aangedui dat omgekeerde korrekte kondoom kennis telling, ouderdom tydens eerste vaginale seks en HIVIVIGS erns voorspelbaar was vir HIVIVIGS risiko gedreag wat $53 \%$ van die afwyking verklaar het. 


\section{INTRODUCTION}

\section{Problem statement}

Abdool-Karim and Abdool-Karim (2000:3) indicate that the annual national antenatal HIV seroprevalence rate in South Africa rose more than 21-fold from 1990 $(0.76 \%)$ to $1997(16.01 \%)$. At least half of those infected with HIV are under the age of 25, making AIDS a major concern affecting the youth in South Africa today (Lindegger \& Wood, 1995:1). Flisher, Ziervogel, Chalton, Leger and Robertson (1993:595) found among Xhosa-speaking pupils in South Africa a relatively high incidence of sexual activity often with a partner who has been known for a short period of time, and a low incidence of condom use. These findings are alarming since HIV/AIDS is preventable if one remains celibate or practices safe sex.

Condoms are an integral part of STD and HIV/AIDS prevention, and their use has increased significantly over the past decade. Correct use of them reduces the risk of HIV transmission by almost 100 percent. Therefore, condom promotion has received considerable attention in the fight against the AIDS pandemic (World Health Organisation, 1995:3ff.). Yet condom use is among the most difficult issues to address in designing programmes to reduce the sexual transmission of HIV in Africa. Campbell (1997:187) mentions that for sub-Saharan Africa negative attitudes toward condom use are often based on cultural factors, e.g. the desire for children and the fact that female sexual compliance are seen as ways to achieve economic status. Among junior sexually active rural secondary school pupils in the Northern Province more than half of the sexually active males (56\%) and almost one third (18.6\%) of the females reported never to have used condoms. About $30 \%$ of the females were unaware that condoms offer protection against AIDS and sexually transmitted diseases (Peltzer, 2000:37). Among sexually active rural senior secondary school pupils about half of the sexually active (52.6\% males and $40.5 \%$ females) reported never to have used condoms (Peltzer, 2001:52).

In order to design effective education and other interventions to reduce the risk of being infected, it is not only important to know what the knowledge, beliefs, and risk behaviours are, but also what factors are asso- ciated with these risk behaviours, especially for those groups of individuals, such as adolescents, who are at an elevated risk of contracting HIV (Mathai, Ross \& Hira, 1997:563). One's risk of HIV infection is determined by the number of partners one has, the behaviours one engages in with those partners (such as sexual intercourse without the use of a condom), the probability that those partners have HIV/AIDS, and the transmissibility of the disease (Brunham \& Plummer, 1990:1339).

In a study (Epstein, Dusenbury, Botvin \& Diaz, 1994:1043) investigating factors associated with young adolescents' increased risk of contracting AIDS in New York, it was found that AIDS knowledge, substance abuse, decision-making skills, gender, and ethnicity predicted intentions to engage in sexual behaviour in the future. Metzler, Noell, Biglan, Ary and Smolkowski (1994:419) found among American adolescents that those whose peers were reported to engage in diverse problem behaviours were more likely to engage in risky sexual behaviour. Further literature indicates that factors affecting HIV risk reduction are a range of situational, interpersonal and structural factors such as knowledge about AIDS, behavioural intention, perceived vulnerability, perceived barriers, selfefficacy, and demographic factors (Basen-Enquist, 1992:120, Basen-Engquist, Mâsse, Coyle, Kirby, Parcel, Banspach \& Nodora, 1999:25, Bengel, Belz-Merk \& Farin, 1996:505).

\section{Aim}

There is a lack of studies on factors influencing HIV risk reduction among younger age groups despite the fact that HIV infection rates have become increasingly higher among adolescents. Therefore, the purpose of this study was to identify factors affecting HIV risk reduction among junior secondary school pupils in South Africa.

\section{Objectives}

- To identify the association between biographic factors, sexual history, health beliefs, condom use knowledge, behavioural and subjective norms to use condoms, normative beliefs to use condoms, attitudes towards condom use and condom use intention with HIV risk 
behaviour.

- To identify independent predictors for HIV risk behaviour.

\section{METHODS}

\section{Sample and procedure}

The sample consisted of 446 Grade 10 , Secondary School pupils chosen from the total Grade 10 population throughout one region in the Northern Province. The participants were randomly sampled within gradelevel and gender, using class registers. There were no drop outs from this sample. The pupils were 200 $(44.8 \%)$ males and $241(55.2 \%)$ females in the age range of 16 to 25 years ( $M$ age $16.3 \mathrm{yr}, \mathrm{SD}=2.3$ ). More than 84 percent came from a rural background while 15.4 came from an urban background.

In this study only those cases were analysed who had had a sexual experience. These were 144 in total, 70 female and 74 male. The following sample size therefore only included people from this sample. It is constituted as follows: Northern Sotho (101: 70\%), Tsonga (23: $16 \%)$, Venda (7: $5 \%$ ), Ndebele (6: $4 \%)$, and others $(7: 5 \%)$.

The pupils were clearly informed that the purpose of the survey was to find out about the use and knowledge of condoms and that their responses would be treated as totally anonymous and confidential. Each student was requested to complete the questionnaire after requested to give his or her informal consent or indicate that he or she did not want to do so. Permission was obtained from the parents where necessary, the Department of Education and the principals of the respective schools.

\section{Inventory}

The instrument, which was essentially a questionnaire, was pre-tested on 15 male and 15 female pupils, who did not form part of the final sample. The final questionnaire consisted of the following kinds of questions:

(a) Biographic data (6 items);

(b) Sexual activity and condom use (12 items);

(c) Knowledge of correct condom use (10 items)
(Sharma, Dave, Sharma \& Chauhan, 1997:710);

(d) Intention of using condoms (when having sex next time with a new partner) (1 item) (from $2=$ strongly agree to $+2=$ strongly disagree);

(e) Behavioural norms to use condoms (3 items), such as "Do you and do your friends talk about using condoms?" (rated 1=Yes, -1=No, 0=Don't know);

(f) Attitudes towards condoms ( 3 items) such as: "It is a good idea for me to use condoms?" (rated from $-2=$ strongly agree to $+2=$ strongly disagree);

(g) Normative beliefs about condoms (3 items referring to parents, sex partners, close friends), such as: "My parents think I should use condoms" (rated from $-2=$ strongly agree to $+2=$ strongly disagree) (Bengel et al. 1996:508);

(h) Subjective norms about condoms (Most people who are important to me think I should use condoms) ( 1 item) (rated from $-2=$ strongly agree to $+2=$ strongly disagree);

(i) Two subscales (HIV/AIDS vulnerability or likelihood to get it and severity in the country, 8 items) taken from the AIDS Health Belief Scale (AHBS), developed by Zagumny and Brady (1998:173). Cronbach alpha as well as split-half reliability coefficients for the AIDS Health Belief Scale were .89 and .83 for this sample.

The HIV/AIDS risk index included the following items: (i) History of sexually transmitted diseases, (ii) Had sex under the influence of alcohol, (iii) Frequency of vaginal sex during the last 3 months (without condom), (iv) Frequency of oral sex during the last 3 months without condom, (v) Frequency of anal sex during the last 3 months without condom, (vi) Number of sexual partners in the last 12 months, (vii) Frequency of vaginal intercourse in the past 3 months with a 'casual' partner, (viii) Frequency of vaginal intercourse in the past 3 months with a commercial sex worker, and (ix) duration of a relationship of less than seven days before sexual intercourse. Cronbach alpha as well as splithalf reliability coefficients for the HIV/AIDS risk index were .69 and .66 for this sample.

\section{Data analysis}

The data analysis techniques used included the Pearson correlations and stepwise multiple regression analysis using the Social Sciences Statistical Package (SPSS version 8.0). 


\section{RESULTS}

Table 1 indicates descriptive and bivariate analyses for the HIV/AIDS risk index.

Table 1: Descriptive and bivariate analyses for the HIV/AIDS risk index

\begin{tabular}{|l|l|l|l|}
\hline Variable & M & SD & $\begin{array}{l}\text { Pearson } \\
\text { Correlation }(r)\end{array}$ \\
\hline 1. Sex & & & .045 \\
\hline 2. Age at first vaginal intercourse & 15.2 & 2.3 & $.318^{* * *}$ \\
\hline 3. HIV/AIDS susceptibility & 13.8 & 5.6 & $.451^{* * *}$ \\
\hline 4. HIV/AIDS severity & 15.7 & 5.7 & $.372^{* *}$ \\
\hline 5. Correct condom use knowledge & 7.0 & 2.1 & $-.344^{* *}$ \\
\hline 6. Behavioural norms to use condoms & 0.9 & 1.5 & -.110 \\
\hline 7. Attitudes towards condom use & 0.5 & 1.3 & $.193^{*}$ \\
\hline 8. Normative beliefs to use condoms & -1.3 & 3.3 & $.281^{* *}$ \\
\hline 9. Subjective norms to use condoms & -0.6 & 1.4 & $.326^{* *}$ \\
\hline 10. Condom use intention & -0.2 & 1.5 & $-.364^{* * *}$ \\
\hline
\end{tabular}

(Item 10 was reverse scored), ${ }^{* * *} p<.001,{ }^{* *} p<.01,{ }^{*} p<.05$

The mean age of first sexual intercourse among the sexually active group was 15.2 years. A mean score of 7.0 (range from $0-10$ ) on the correct condom use seems to indicate a fair degree of knowledge. High mean rates were found for HIV/AIDS perceived severity (15.7) and vulnerability (13.8).

Bivariate analysis found positive significant relations between age at first vaginal intercourse, HIV/AIDS susceptibility and severity, attitudes towards condoms, normative beliefs to use condoms as well as subjective norms to use condoms and the HIV/AIDS risk index; inversely related were correct condom knowledge and condom use intention. Sex and behavioural norms to use condoms were not significantly associated with the HIV/AIDS risk index.

\section{Regression analysis}

Only the variables, which showed a correlation with the HIV/AIDS risk index, were included in the equation. The stepwise Multiple Regression analysis is shown in Table2.

Table 2: Regression analysis with HIV/AIDS risk behaviour as dependent variable

\begin{tabular}{|l|l|l|l|l|}
\hline Variable & B & Beta & t value & Sign \\
\hline HIV/AIDS susceptibility & .231 & .255 & 1.955 & .059 \\
\hline Condom knowledge score & -.966 & -.351 & -3.602 & .001 \\
\hline Age at first vaginal sex & .659 & .319 & 3.289 & .002 \\
\hline HIV/AIDS severity & .322 & .331 & 2.488 & .016 \\
\hline
\end{tabular}

Multiple $\mathrm{R}=.728 ; \mathrm{R}^{2}=.530 ;$ Fratio $16.6 ;$ d.f. $=4 ; p<.0001$
The regression analysis indicated that inversely correct condom knowledge score, age at first vaginal sex and HIV/AIDS severity were found to be predictive for HIV/AIDS risk behaviour. The model accounted for $53 \%$ of the variance. Excluded from the equation were: normative beliefs to use condoms, subjective norms to use condom, attitudes towards condoms use, and the intention to use condoms.

\section{DISCUSSION}

A higher HIV/AIDS severity predicts higher HIV risk behaviour. This can be explained by the existence of the collective belief of getting HIV anyway so that HIV prevention behaviour is therefore abandoned. Among the Zulu youth in South Africa Leclarc-Madlala (1997:363) found that those who suspect they may be infected with HIV will avoid a definite diagnosis while at the same time endeavouring to spread the infection as widely as possible.

This study identified correct condom knowledge as a lower HIV risk behaviour, which is confirmed by most studies (e.g. Bandawe \& Foster, 1996:125). Contrary to a number of other studies (e.g. Bandawe \& Foster, 1996:126, Bengel et al. 1996:510), this study did not find behavioural and subjective norms to use condoms, attitudes towards condoms, and normative beliefs to use condoms as independent predictors for the HIV/ AIDS risk index. In line with other literature it was found that factors affecting HIV risk reduction are a range of situational, interpersonal and structural factors such as knowledge about correct condom use, perceived severity, perceived susceptibility, and demograhic factors (Basen-Engquist, 1992:120, Bengel et al. 1996:505).

The finding that age at first vaginal intercourse was positively related to high risk behaviour may be explained by factors such as an increase in the number and type of sexual partners, a history of a sexually transmitted disease and the frequency of sex with increasing age. Flisher et al. (1993:596) states that age at first intercourse may be a poor indicator of risk owing to the possibility of a long time interval between the first and subsequent sexual encounters, and the infrequency of sexual intercourse. The mean age of 15.2 years for first sexual intercourse in this sexually active 
group was similar to that found by Buga, Amoko \& Ncayiyana (1996:98) among school girls $(M=14.86 \mathrm{yr}$, $\mathrm{SD}=1.81$ ) in the Eastern Cape, South Africa, and lower than among the youth (16.4 years) in the eastern part of the Northern Province of South Africa (Peltzer \& Seoka, in print).

Further investigation is needed on the predictive factors of HIV risk behavior such as correct condom use knowledge, HIV/AIDS severity and vulnerability as well as age at first vaginal intercourse, and they should be included in HIV prevention intervention programmes.

\section{Acknowledgement}

The research was supported by a grant from the University of the North.

\section{REFERENCES}

Abdool-Karim, Q \& Abdool-Karim, SS 2000: Epidemiology of HIV in South Africa. Durban: Medical Research Council.

Bandawe, CR \& Foster, D 1996: AIDS-related beliefs, attitudes and intentions among Malawian students in three secondary schools. AIDS CARE, 8:223-232.

Basen-Engquist, K 1992: Psychosocial predictors of "safer sex" behaviors in young adults. AIDS Education and Prevention, 4:120-134.

Basen-Engquist, K; Mâsse, LC; Coyle, K; Kirby, D; Parcel, GS; Banspach, S \& Nodora, D 1999: Validity of scales measuring the psychosocial determinants of HIV/STD-related risk behavior in adolescents. Health Education Research, 14:25-38.

Bengel, J; Belz-Merk, M \& Farin, E 1996: The role of risk perception and efficacy cognitions in the prediction of HIV-related preventive behavior and condom use. Psychology and Health, 11:505525.

Brunham, R \& Plummer, F 1990: A general model of sexually transmitted disease epidemiology and its implications for control. Medical Clinics of North America, 74:1339-1352.

Buga, GAB; Amoko, DHA \& Ncayiyana, DJ 1996: Adolescent sexual behaviour, knowledge and attitudes to sexuality among school girls in Transkei, South Africa. East African Medical Journal, 73:95100.

Campbell, T 1997: How can psychological theory help promote condom use in sub-Saharan African developing countries. Journal of the Royal Society of Health, 117:186-191.

Epstein, JA; Dusenbury, L; Botvin, GJ \& Diaz, T 1994: Determinants and intentions of Junior High School students to become sexually active and use condoms: implications for reduction and prevention of AIDS risk. Psychological Reports, 75:1043-1053. Flisher, AJ; Ziervogel, CF; Chalton, DO; Leger, PH \& Robertson, BA 1993: Risk-taking behaviour of Cape Peninsula high-school students: Part VIII. Sexual behaviour. South African Medical Journal, 83:595-597.

Leclarc-Madlala, S 1997: Infect one, infect all. Zulu youth response to the AIDS epidemic in South Africa. Medical Anthropology, 17:363-380.

Lindegger, G \& Wood, G 1995: The AIDS crisis: review of psychological issues and implications, with special reference to the South African situation. South African Journal of Psychology, 25:111.

Mathai, R; Ross, MW \& Hira, S 1997: Concomitants of HIV/AIDS risk behaviours and intention to engage in risk behaviours in adolescents in India. AIDS CARE, 9:563-576.

Metzler, CW; Noell, J; Biglan, A; Ary, D \& Smolkowski, K 1994: The social context for risky sexual behaviour among adolescents. Journal of Behavioral Medicine, 17:419-438.

Peltzer, K 2000: Factors affecting condom use among junior Secondary School pupils in South Africa. Health SA Gesondheid, 5(2):37-44.

Peltzer, K 2001: Factors affecting behaviors that address HIV risk among senior

secondary school pupils in South Africa. Psychological Reports, 89:51-56.

Peltzer, K \& Seoka, P (in print) HIV/AIDS/STD knowledge, attitudes, beliefs and behaviours in rural South African youth: implications for health education. African Journal for Physical, Health Education, Recreation and Dance.

Sharma, V; Dave, S; Sharma, A \& Chauhan, P 1997: Condoms: misuse=non-use: the condom equation in Gujarat, India. AIDS

CARE, 9:707-713.

World Health Organisation 1995: Condom promotion for AIDS prevention. Geneva: WHO.

Zagumny, MJ \& Brady, DB 1998: Development of the AIDS Health Belief Scale (AHBS). AIDS Education and Prevention, 10:173-179. 


\section{Requirements to which the authors of articles must conform}

\section{Copyright reserved}

The submission of an article to the editorial staff of Health SA Gesondheid shall be deemed as tacit connect that the copyright to the article be reserved by Health SA Gesondheid. In addition, the article shall be assumed to be an original work that has never been published before. Requests for permission to reprint material from this journal should be directed to the Editor at the address below. The editorial staff shall not accept responsibility for any printouts or hard discs ("stiffies") of such article being damaged or lost.

The following statement signed by all the authors must accompany submitted articles: "The undersigned author/s transfer(s) to Health SA Gesondheid (published by RAU) all copyright of which he/she is the owner in respect of the manuscript entitled ... (title of article), in the event that the work is published. In the event that the copyright subsists in someone other than the author, she/he warrants that copyright in the manuscript may be so transferred. The undersigned author/s warrant(s) that the article is original, is not under consideration by another journal, and has not been previously published."

\section{Nature of the publication}

Health SA Gesondheid is an interdisciplinary research journal in which only select articles of the highest scientific standard with human health as the main theme are published. Articles on research work or review articles with the same theme shall also be considered for publication. Journal articles express the authors' views and are not necessarily the views of Health SA Gesondheid. Articles may be written in either Afrikaans or English.

\section{Review}

Each article shall be reviewed on a double-blind basis by at least two selectors. Articles written by any editorial members have also been through a double-blind peer review.

\section{Requirements for publication}

- $\quad$ Articles must be typed in A4 size and in double spacing.

- Three printouts ("hard copies") of the article must be submitted.

- Apart from the above-mentioned printouts, one copy of the article on hard disc ("stiffy") must also be submitted. The latter disc must clearly be marked with the name of each author and co-author, the name of the file and the name of the word processing program used.

- $\quad$ The article must be accompanied by a covering letter.

The title page must give the following particulars:

- The title of the article

- The surname, first name and, if any, the other initials of each author and co-author.

- The academic and professional qualifications of each author and co-author.

- The capacity in which each author and co-author is acting and the name of his or her organisation/institution.

- The author's postal address.

The article must be accompanied by abstracts in English and Afrikaans of no more than 200 words.

The article must be accompanied by 5 keywords used in the article.

The article itself may not compromise more than 17 pages (5 000 words). Authors must supply a word count.

The article must be ready for the press, in other words, it must have been revised for grammar and style. The author must provide a letter from a language editor confirming this.

All references to source books must be acknowledged according to the revised Harvard method.

- All illustrations, figures and tables must be numbered and provided with titles. Each illustration, figure and table must, in addition, appear on a separate page and must be graphically prepared - be press ready. NOT printed on a colour printer.

- Headings are not numbered. Their order of importance is indicated as follows: Main Headings in capitals and bold print; subheadings in upper and lower case and bold letters; sub-sub headings in upper and lower case, bold and italic letters.

- Handling fee charges must be included with the article. An additional account in respect of the printing expenses shall be sent to the author/authors at publication.

Handling fees: $\quad$ R100-00 for subscribers of Health SA Gesondheid

R200-00 for non-subscribers

Applicable on articles received from 2002

Publishing fees: R100-00 per page for subscribers of Health SA Gesondheid R200-00 per page for non-subscribers

Applicable to all articles printed from Volume 7 number 1

Please send the covering letter, the three printouts, the hard ("stiffy") and the handling charges to the following address:

The Editor

Health SA Gesondheid

Department of Nursing Science

Rand Afrikaans University

PO Box 524

AUCKLAND PARK, 2006

All cheques must be made out to Health SA Gesondheid, RAU

Authors/co-authors can contact the editorial staff of Health SA Gesondheid at the following telephone or fax numbers:

Tel. (011) 489-3325

Fax (011) 489-2257

E-mail: hsa@edcur.rau.ac.za 